
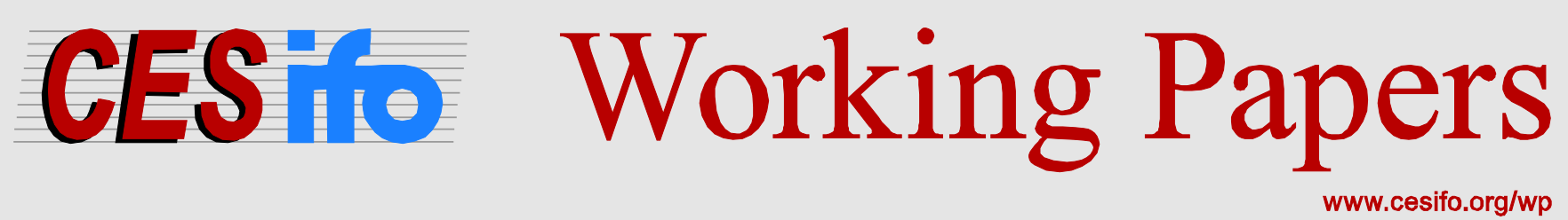

\title{
Investors' Portfolio Choice and Tax Reforms: The 2008 German Corporate Tax Reform Reconsidered
}

\author{
Michael Stimmelmayr \\ CESIFO WORKING PAPER NO. 5311 \\ CATEgory 1: Public FinanCE \\ APRIL 2015 \\ An electronic version of the paper may be downloaded \\ - from the SSRN website: \\ - from the RePEc website: \\ - from the CESifo website: \\ wWw.SSRN.com \\ www.RePEc.org \\ www.CESifo-group.org/wp
}

ISSN 2364-1428

\section{CESifo}




\title{
Investors’ Portfolio Choice and Tax Reforms: The 2008 German Corporate Tax Reform Reconsidered
}

\begin{abstract}
The paper provides a comprehensive assessment of the latest German corporate income and capital tax reform, which entails a major shift of the capital tax burden from the firm to the household level. Using a dynamic two-country computable general equilibrium model with integrated capital markets, we show that economic growth and domestic welfare are negatively affected by the reform. Key to the limited growth is the domestic investors' portfolio choice as a channel for tax avoidance at the household (i.e. investor) level. While international investors may well counteract the negative impact on growth, their privileged tax treatment erodes the domestic capital income tax base and thus creates adverse welfare effects.
\end{abstract}

JEL-Code: H250, G110, F210, D580.

Keywords: portfolio investment, corporate tax reform, foreign firm ownership, computable general equilibrium.

\author{
Michael Stimmelmayr \\ KOF, Swiss Economic Institute \\ ETH Zurich \\ Leonhardstrasse 21 \\ Switzerland - 8092 Zurich \\ Stimmelmayr@kof.ethz.ch
}

This Version: March 2015

I am grateful for the financial support from the Fritz Thyssen Stiftung (Az. 40.10.0.015) and for the stimulating atmosphere at the Oxford University Centre for Business Taxation during my research stay. In addition, I appreciate helpful comments by seminar and conference participants in Munich and Ann Arbor. 


\section{Introduction}

Tax competition is at the core of the tax policy in almost every country. The incentives of national governments to engage in tax competition originate from the fact that capital and profits are mobile across jurisdictions. To gain a competitive edge in attracting these tax bases, governments are tempted to lower the tax rates on capital and profits and, to balance the government budget, to raise the taxes on less mobile tax bases, such as household income. The latest German corporate tax reform, in place since 1 January 2008, largely follows the logic of shifting the capital tax burden from the mobile firm level to the less mobile household level. In detail, the German reform stipulated a reduction in the effective corporate tax burden from above 38 to below 30 per cent, combined with the introduction of a withholding tax of effectively 26.4 per cent on capital income. The withholding tax increased the tax burden on corporate equity holdings, since dividends were taxed at a lower rate prior to the reform and non-speculative capital gains were tax exempt.

In a standard open economy model of corporate tax incidence, shifting the tax burden from a mobile factor like capital (firms) to less mobile entities such as workers or households is largely welfare improving from the national perspective (see Gordon and Hines 2002, Keen and Konrad 2013, Kotlikoff and Summers 1987 or Sinn 2003, for instance). A similarly beneficial outcome to the one discussed in the literature is not confirmed in the case of the German 2008 reform. Our findings point to a negative welfare effect and only a poor growth stimulus resulting from the reform. Despite the substantial reduction in the corporate tax burden, output growth and corporate investment activity have been negatively affected by the reform. The explanation for this unexpected result is related to the fact that household income has become more mobile with the integration of international capital markets. In particular, the tax-induced portfolio choice of domestic households has created a shortage of domestic corporate investment funds, counteracting the intended growth stimulus of the reform. ${ }^{1}$ Our paper thereby contributes to the existing literature by broadening the understanding of the incidence of capital income taxation and of tax avoidance in the presence of foreign portfolio investments (FPIs). Possibly surprisingly, the interaction between taxes and FPIs has received relatively little attention vis-à-vis the analysis of the tax consequences for foreign direct investments (FDIs), even though FPIs are quantitatively much more important

\footnotetext{
${ }^{1}$ The introduction of the withholding tax raises the domestic households' tax burden on corporate equity vis-a-vis interest-bearing assets and thus encourages households (investors) to restructure their portfolios in favour of firm or government bonds. This tax-induced reluctance of domestic investors to hold corporate equity constrains corporate investment funds and thus investment activity. Interestingly, the portfolio shift towards interest-bearing assets confirms the analysis by Fuest and Huber (2000), who state that the German tax system prior to the 2008 reform had created a substantial portfolio bias in favour of domestic equity. The bias was revoked by the introduction of the uniform withholding tax on capital income.
} 
than FDIs (see Slemrod et al 1996). ${ }^{2}$ To the best of our knowledge, the few exceptions in the existing literature that explicitly consider the role of capital income taxation in the presence of FPIs are the papers by Devereux (2000, 2004), Fuest and Huber (2000) and Gordon and Gaspar (2001).

The second noteworthy contribution of the analysis relates to the twofold role of international investors in the ramifications of the reform. In view of the current tax practice, international investors face a privileged withholding tax treatment or even complete exemption from withholding taxes compared with domestic investors. ${ }^{3}$ This tax asymmetry positively affects international investors' incentive to hold domestic equity and hence partly compensates for the lack of corporate investment funds originating from the tax-induced portfolio choice of domestic investors. The significant positive impact on investments and economic growth arising from the privileged tax treatment of international investors, however, does not translate into a beneficial welfare outcome. The reduction in the corporate tax rate, in addition to the privileged taxation of international investors, raised the costs of the reform substantially such that tax revenues and welfare dropped in the aftermath of the 2008 reform. In general equilibrium, the erosion of the capital income tax base is additionally magnified by the domestic investors' tax incentive to sell off corporate equity holdings, which caused a significant rise in the share of foreign firm ownership after the reform.

The simulation results are in line with the general insight that international ramifications have a significant impact on the welfare effects of tax reforms (see Mendoza and Tesar, 1998, among others). We should, however, note that in our analysis the specific role of international investors differs from that emphasized in the literature on tax policies in open economies. The existing papers, such as Huizinga and Nielsen (1997, 2002), point out the incentives of governments to shift part of the source-based tax burden onto international investors. This is different in our analysis. Under a residence-based tax system, international investors are fiscally distinct from domestic investors, undermining the national policy incentives to switch from a source-based to a residence-based tax system, as was partially implemented by the German 2008 reform.

Closely related to our paper, Haufler (1999) discusses the problems arising from the European Commission's 1998 proposal for an EU-wide withholding tax on interest income for

\footnotetext{
${ }^{2}$ In the German case, about two-thirds (60.9 per cent at the end of 2013) of the foreign wealth of German firms and German private households is held in the form of portfolio investments, while only one-third (33.8 per cent) is held in the form of foreign direct investment (German Central Bank, 2014).

${ }^{3}$ The OECD Double Tax Convention (OECD 2010) stipulates that the capital income of foreign investors is in general taxed according to the residence principle; additionally, the convention limits the source country's levy of withholding taxes on the dividends or interest income of foreign (in particular European) investors who hold a significant share of the dividend- or interest-paying company (see OECD 2010 and EU Council Directives 2003/123/EC, 2003/49/EC 2011/96/EU and COM/2011/714/FINAL).
} 
EU residents but excluding international investors. Haufler concludes that the discriminatory withholding tax treatment of domestic and foreign investors is harmful, as it might result in undesirable distributional consequences and it is ineffective for raising revenues. Sørensen (2001 and 2002) quantifies the effects arising from national tax policies and international tax coordination within OECD countries on international portfolio holdings of households. In his 2002 paper, Sørensen applies a general equilibrium model of the OECD economy to quantify the ramification of the previous 2000 German corporate tax reform, which was the first attempt to shift the tax burden from the firm to the household level. Fuest and Huber (2000), also discuss the effects of the previous 2000 German tax reform. Interestingly, the authors highlight that the 2000 reform introduced a major tax incentive for domestic investors to hold corporate equity instead of debt (bonds) and that it created tax discrimination of foreign investors holding domestic corporate equity. In line with the predictions by Fuest and Huber, our results confirm that the adjustments in the portfolio holdings after the 2008 reform appear on exactly these two margins. This indicates that the 2008 reform alleviated the pre-existing distortions in the portfolio choice (corporate equity versus bonds) and asset ownership (domestic versus foreign ownership).

There is little literature on the evaluation of the 2008 German tax reform. The existing studies, such as Finke et al (2010) or Radulescu and Stimmelmayr (2010), mainly focus on the revenue consequences or (similar to this paper) on the growth and welfare effects of the 2008 reform. However, contrary to this study, they do not focus on the international ramifications arising from the tax-induced portfolio choice of investors or foreign firm ownership. ${ }^{4}$

The paper proceeds as follows: Section 2 presents a short non-technical summary of the applied computable general equilibrium (CGE) model. The impact of capital income taxes on the investors' portfolio choice is analysed in Section 3. The main elements of the 2008 German corporate tax reform are explained in Section 4 and the simulation results are presented in Section 5. Section 6 concludes.

\section{The Applied CGE Model}

The dynamic computable general equilibrium (CGE) model builds on neoclassical growth theory and accounts for various behavioural margins of firms and households. The model covers firms of different legal forms, including corporate and non-corporate firms, which differ with regard to their inherent characteristics and legal tax treatment. Each firm maximizes

\footnotetext{
${ }^{4}$ There is a sizeable theoretical literature on the role of globalization, such as price changes in international markets and foreign ownership of assets, in tax policy. See Keen and Konrad (2013) for a review. The literature does not aim to quantify these effects using actual tax reforms.
} 
its profits by optimizing its investment, source of finance and labour inputs. Firms' financial decision is endogenous with regard to the choice between debt and equity finance. In line with Pfaffermayr et al (2013), we assume that corporate firms are more mature than unincorporated firms and thus are less contingent on debt finance, that is, have a lower debt-asset ratio than unincorporated firms. ${ }^{5}$ Besides interest payments, debt finance incurs extra costs, reflecting the additional charge that banks levy from heavily indebted firms due to their higher risk of default. Equity finance includes retained earnings and new share issues. ${ }^{6}$ To capture the behavioural implications arising from the German tax law, we account for all the relevant profit and capital income taxes levied at the different federal levels (including the local trade tax and the solidarity surcharge) as well as the most important tax deductions available. Hence, the model provides deeper insights into the impact of capital income taxation on firms' investment and financing behaviour as well as their employment decision.

The household sector consists of a representative agent, which maximizes life-time utility. The agent decides on optimal inter-temporal consumption and optimal labour supply in the presence of a value added tax (VAT) and a progressive wage tax schedule. The optimal consumption choice implicitly determines household savings and thus the amount of portfolio investment. The endogenous portfolio choice embedded, allows the agent to invest savings in different types of imperfectly substitutable assets, comprising firm equity, firm bonds, and domestic or foreign government debt. Hence, the framework capture the tax-induced distortions in international capital flows originating from domestic (and foreign) households' portfolio choices. The equivalent variation serves as our measure of welfare.

The government levies taxes on firms and households and incurs debt. Government income is spent on public consumption and its budget is balanced via lump-sum transfers to households. The debt to GDP ratio is kept constant at its long-run average. In general equilibrium, the present value of all future tax income equals government spending plus government debt to ensure that the inter-temporal budget constraint holds. The foreign economy, that is, the rest of the world, is in structure identical to the domestic economy, but it is modelled in less detail. The two economies engage in trade and we allow for cross-country ownership of assets.

Altogether, the model represents a dynamic, micro based two-country macro model in

\footnotetext{
${ }^{5}$ This implicit assumption about firm age also explains the stronger response in financing behaviour of corporate vis-à-vis unincorporated firms arising from a variation in the corporate tax rate. Confirming Pfaffermayr et al (2013), the change in the debt-asset ratio of corporate vis-à-vis unincorporated firms is almost twice as large in response to the tax rate changes accompanying the 2008 reform (see Tables 6 and 7 ).

${ }^{6}$ Following the empirical evidence on the prevalence of retained earnings as the source of investment funds, the calibration of the model is biased in favour of the 'New View' of dividend taxation (see Auerbach 1979, Bradford 1981 or Sinn 1991, for instance).
} 
which the foreign economy is relatively large compared with the home economy. The decisions of all economic agents are forward looking and originate from an inter-temporal optimization problem. Optimal behavioural responses are coordinated by prices that equalize the supply and demand. The dynamic feature of the model enables us to capture the tax capitalization effects associated with investment and savings decisions, which, by nature, are forward looking. Each sector is calibrated to capture in detail the characteristics of the German economy. A comprehensive introduction to the model is available in Radulescu and Stimmelmayr (2010) or Stimmelmayr (2007). ${ }^{7}$ Given the dominant role of the investors' portfolio choice in this analysis, it is characterized in detail in the next section.

\section{Portfolio Choice and Saving Behaviour}

The representative agent is modelled as an infinitely lived household, which accounts for the utility of future generations at the rate $\rho<1$. The value function mapping the household's preferences is stated as

$$
U^{*}\left(A_{t}\right)=u\left\{C_{t}-\varphi\left(l_{t}^{S}\right)\right\}+\rho U^{*}\left(A_{t+1}\right)
$$

$A_{t}$ denotes the investor's portfolio wealth, $C_{t}$ represents consumption and $\varphi\left(l_{t}^{S}\right)$ is the disutility of work arising from the individual labour supply $l_{t}^{S}$. The household maximizes (1) subject to the inter-temporal budget constraint

$$
G A_{t+1}=\left(1+\bar{r}_{t}\right) A_{t}+\left(1-\tau^{L}\right) w_{t} l_{t}^{S}+T R_{t}-\left(1+\tau^{C}\right) C_{t}
$$

Wealth accumulates by means of the portfolio income, $\left(1+\bar{r}_{t}\right) A_{t}$, net of tax labour income, $\left(1-\tau^{L}\right) w_{t} l_{t}^{S}$, and lump-sum transfers, $T R_{t}$, and less gross consumption expenditures, $(1+$ $\left.\tau^{C}\right) C_{t}$. The variable $G=1+g$ reflects the exogenous growth factor in the economy and $\bar{r}_{t}$ denotes the average net-of-tax portfolio return that originates from the investor's optimal portfolio choice problem. $\tau^{L}$ and $\tau^{C}$ denote the tax rates on labour income and consumption, respectively.

Portfolio wealth

$$
A_{t}=\sum_{n}^{5} A^{n} \quad \text { with } \quad n \in\left\{V^{f \in\{C, N C\}}, B, D^{j \in\{H, F\}}\right\} .
$$

\footnotetext{
${ }^{7}$ Other CGE models that are predominantly dedicated to tax policy analysis in European economies include the models by De Mooij and Devereux (2011), Dietz and Keuschnigg (2004, 2007) and Sørensen (2001), for instance. All these models, however, differ with respect to their model structure and the reforms analysed. See Peichl (2008) for a comparison of the different models.
} 
consists of corporate and non-corporate firm equity, $A^{V^{f}}, f \in\{C, N C\}$, firm bonds, $A^{B}$, as well as domestic and foreign government bonds, $A^{D^{j}}, j \in\{H, F\}$. All domestic assets except for non-corporate firm equity, $A^{V^{N C}}$, are internationally trade-able and are thus partly foreign owned.

The five different types of assets are grouped into three classes, covering firm equity $\left(V^{f}\right)$, firm bonds $(B)$ and government bonds $\left(D^{j}\right)$. While the various assets within each class are perfect substitutes, the asset classes themselves are imperfect substitutes. This approach reflects a reduced form modelling of inherently different default probabilities for the various asset classes without having to account explicitly for uncertainty, risk aversion and differences in risk characteristics across the asset classes (see also Dietz and Keuschnigg 2004, 2007 or Sørensen (2002) for a similar approach).

Table 1: Gross and Net Return of Assets

\begin{tabular}{|c|c|c|}
\hline Asset Classes & Gross Return & Net Return \\
\hline \multicolumn{3}{|l|}{ Firm Equity } \\
\hline$A^{V^{C}}:$ & $i_{t}^{V^{C}}=\frac{\chi_{t}^{C}}{V_{t}^{C}}+\frac{\left[G V_{t+1}^{C}-V_{t}^{C}-V N_{t}\right]}{V_{t}^{C}}$ & $r_{t}^{V^{C}}=\frac{\left(1-\tau^{D}\right) \chi_{t}}{V_{t}^{C}}+\frac{\left(1-\tau^{G}\right)\left[G V_{t+1}^{C}-V_{t}^{C}-V N_{t}\right]}{V_{t}^{C}}$ \\
\hline$A^{V^{N C}}:$ & $i_{t}^{V^{N C}}=\frac{\pi_{t}^{N C}}{V_{t}^{N C}}+\frac{\left[G V_{t+1}^{N C}-V_{t}^{N C}\right]}{V_{t}^{N C}}$ & $r_{t}^{V^{N C}}=\frac{\left(1-\tau^{P^{N C}}\right) \pi^{N C}}{V_{t}^{N C}}+\frac{\left(1-\tau^{G}\right)\left[G V_{t+1}^{N C}-V_{t}^{N C}\right]}{V_{t}^{N C}}$ \\
\hline \multicolumn{3}{|l|}{ Firm Bonds } \\
\hline$A^{B}:$ & $i_{t}^{B}$ & $r_{t}^{B}=\left(1-\tau^{i}\right) i_{t}^{B}$ \\
\hline \multicolumn{3}{|c|}{ Government Bonds } \\
\hline$A^{D^{H}}:$ & $i_{t}^{D^{H}}$ & $r_{t}^{D^{H}}=\left(1-\tau^{i}\right) i_{t}^{D^{H}}$ \\
\hline$A^{V^{F}}:$ & $i_{t}^{D^{F}}$ & $r_{t}^{D^{F}}=\left(1-\tau^{i}\right) i_{t}^{D^{F}}$ \\
\hline
\end{tabular}

Source: Own calculation.

Table 1 summarizes the gross and net returns of the different types of assets. The gross return on corporate equity, $i_{t}^{V^{C}}$, is determined by the amount of the dividend payout, $\chi_{t}^{C}$, and capital gains, $\left[G V_{t+1}^{C}-V_{t}^{C}-V N_{t}\right]$, per unit of firm value, $V_{t}^{C}$. $V N_{t}$ refers to the equity capital injections by firm owners, that is, new share issues. The respective net return on corporate equity, $r_{t}^{V^{C}}$, consists of the net-of-tax dividend payout, $\left(1-\tau^{D}\right) \chi_{t}^{C}$, and net-of-tax capital gains, $\left(1-\tau^{G}\right)\left[G V_{t+1}^{C}-V_{t}^{C}-V N_{t}\right]$, with $\tau^{D}$ and $\tau^{G}$ representing the tax on dividends and capital gains, respectively. Corporate payout, $\chi_{t}^{C}$, corresponds to net-of-corporate tax profits, that is, $\chi_{t}^{C}=\left(1-\tau^{P^{C}}\right) \pi^{C}$ with $\tau^{P^{C}}$ denoting the effective corporate tax rate inclusive 
of the local trade tax and the solidarity surcharge.

The gross return on unincorporated firm equity, $i_{t}^{V^{N C}}$, comprises firm profits, $\pi_{t}^{N C}$, and capital gains, $\left[G V_{t+1}^{N C}-V_{t}^{N C}\right]$, while the net return, $r_{t}^{V^{N C}}$, consists of the net-of-tax payout, $\left(1-\tau^{P^{N C}}\right) \pi^{N C}$, and net-of-tax capital gains, $\left(1-\tau^{G}\right)\left[G V_{t+1}^{N C}-V_{t}^{N C}\right] . \tau^{N C}$ denotes the effective tax rate on non-corporate firm profits (again inclusive of the local trade tax and the solidarity surcharge). Interest-bearing bonds, such as firm bonds and government bonds, yield a net-of-tax return of $r^{k}=\left(1-\tau^{i}\right) i^{k}$, with $k \in\left\{B, D^{j}\right\}$ and $j \in\{H, F\}$, where $\tau^{i}$ denotes the tax rate on the interest income and $i^{k}$ represents the gross return of the respective asset type. Due to imperfect substitutability, the net returns of the different asset classes are not equalized, i.e. $r_{t}^{V^{f}} \neq r_{t}^{B} \neq r_{t}^{D^{j}} .8$

As we are predominantly interested in the effects of domestic capital income taxation on the cross-holding of domestic assets, we abstract from a detailed modelling of domestically owned foreign assets except for foreign government bonds. ${ }^{9}$

The average, net-of-tax return of the domestic investor's portfolio is stated as

$$
\bar{r}_{t}=\sum_{f} \frac{r_{t}^{V^{f}} A_{t}^{V^{f}}+\left(1-\tau^{i}\right) \sum_{k} i_{t}^{k} A_{t}^{k}}{A_{t}}, \quad f \in\{C, N C\}, k \in\left\{B, D^{j \in\{H, F\}}\right\} .
$$

Given that the return differentials between asset classes are substantially affected by capital income taxes, investors adjust their portfolio holdings to maximize the average netof-tax return of their portfolio.

The maximand for the optimal portfolio composition is, $A_{t}^{C}$, is

$$
\begin{gathered}
A_{t}^{C}=\max _{A_{t}^{n}}\left[\sum_{n}^{5}\left(\alpha^{n}\right)^{\frac{1}{1+\sigma^{A}}}\left[\left(1+r_{t}^{n}\right) A_{t}^{n}\right]^{\frac{\sigma^{A}}{1+\sigma^{A}}}\right]^{\frac{1+\sigma^{A}}{\sigma^{A}}} n \in\left\{V^{f \in\{C, N C\}}, B, D^{j \in\{H, F\}}\right\} . \\
\text { s.t. } \quad A_{t}=\left(a_{t}^{V^{C}}+a_{t}^{V^{N C}}+a_{t}^{B}+a_{t}^{D^{H}}+a_{t}^{D^{F}}\right) A_{t},
\end{gathered}
$$

where $\alpha_{t}^{n}$ represents the specific preference parameter for each asset type and $a_{t}^{n}$ denotes the respective unit asset demand. ${ }^{10}$ The solution to the portfolio choice problem yields the optimal demand for each asset type, $A_{t}^{n^{*}}$, which depends on the asset' s net-of-tax return

\footnotetext{
${ }^{8}$ The degree of imperfect asset substitutability is driven by the elasticity of asset substitution, $\sigma^{A}$. The larger the elasticity, the higher is the degree of substitutability between the different asset classes.

${ }^{9}$ This assumption keeps the analysis tractable and has no qualitative impact on the optimal re-structuring of domestic portfolio holdings due to domestic capital income taxation. Any tax-induced substitution between domestic and foreign assets will be captured by the varying amount of foreign government bonds held in the domestic portfolio.

${ }^{10}$ The explicit expression for the preference parameter $\alpha_{t}^{n}$ is $\frac{A_{t}^{n}}{\left(1+r_{t}^{n}\right)^{\sigma^{A}}} / \sum_{n}^{5} \frac{A_{t}^{n}}{\left(1+r_{t}^{n}\right)^{\sigma^{A}}}$, which serves as an important measure when calibrating the model.
} 
factor, $R_{t}^{n}=1+r_{t}^{n}$, relative to the return factor of the composite portfolio, $R_{t}^{C}=1+r_{t}^{C} \cdot{ }^{11}$

$$
A_{t}^{n^{*}}=\alpha^{n}\left[\frac{1+r_{t}^{n}}{1+r_{t}^{C}}\right]^{\sigma^{A}} A_{t}, \quad \text { with } \quad R_{t}^{C}=\left[\sum_{n}^{5} \alpha^{n}\left(1+r_{t}^{n}\right)^{\sigma^{A}}\right]^{1 / \sigma^{A}}
$$

The outlined portfolio choice problem is representative for the domestic investor, but holds analogously for the foreign investor, for whom the domestic interest rates and domestic tax parameters are substituted by the respective foreign variables.

In line with the OECD Model Convention and the EU Directives 2003/123/EC, 2003/49/EC and 2011/96/EU, according to which all earned (capital) income is subject to taxation in the investors' country of residence, we apply the residence principle of taxation. Thus, no withholding taxes apply at source and all earned (capital) income is taxed in the country of residence of the investor. With no withholding taxes at source, the gross rates of return earned on each type of asset $A^{k}, k \in\left\{B, D^{j}\right\}$ and $j \in\{H, F\}$ equalize across countries, that is, $i_{t}^{k, H}=i_{t}^{k, F}$, while the net-of-tax returns differ due to country-specific capital income tax rates, that is, $r_{t}^{k, H} \neq r_{t}^{k, F}$, if $\tau^{i, H} \neq \tau^{i, F} .^{12}$

As a consequence of the residence principle, an increase in the domestic tax on interest income, $\tau^{i}$, encourages investors to substitute interest bearing assets, $A^{k}, k \in\left\{B, D^{j}\right\}$ and $j \in\{H, F\}$ for firm equity, $A^{V^{f}}, f \in\{C, N C\}$. The comparative static analysis is stated as

$$
\begin{gathered}
\frac{A_{t}^{k}}{A_{t}^{V}}=\frac{\alpha^{k}}{\alpha^{V}}\left[\frac{1+\left(1-\tau^{i}\right) i^{k}}{1+\left[\left(1-\tau^{D}\right) \frac{\left(1-\tau^{P}\right) \pi_{t}}{V_{t}}+\left(1-\tau^{G}\right) \frac{\left[G V_{t+1}-V_{t}-V N_{t}\right]}{V_{t}}\right)}\right]^{\sigma^{A}} \\
\Rightarrow \quad \frac{d\left(\frac{A^{k}}{A^{V}}\right)}{d \tau^{i}}<0 \quad \text { and } \quad \frac{d\left(\frac{A^{k}}{A^{V}}\right)}{d \tau^{D}, \tau^{P}, \tau^{G}}>0 .
\end{gathered}
$$

Differently, an increase in the corporate tax rate, $\tau^{P}$, the dividend tax rate, $\tau^{D}$, or the capital gains tax rate, $\tau^{G}$, respectively, induces a replacement of firm equity with interest-bearing assets in the investor's portfolio. ${ }^{13}$

Besides the direct tax effect on the portfolio choice, gross asset returns are also indirectly affected by capital income taxes via supply effects. For instance, an increase in the corporate tax rate diminishes corporate investments and hence the amount of outstanding corporate equity. In turn, the shortage creates upward pressure on the gross rate of return of corporate

\footnotetext{
${ }^{11}$ The net-of-tax return factor of the composite portfolio, $R^{C}$, is determined by the weighted average of the net-of-tax returns on each of the five types of assets, $A^{n}$, where the asset-specific preference parameter $\alpha^{n}$ serves as the weight.

${ }^{12}$ Differently, in the case that withholding taxes are levied at source, the net-of-tax returns equalize across countries, while the gross rates of return remain unequal.

${ }^{13}$ The return differentials between domestic assets depend positively on the asset specific taste parameters $\alpha^{n}, n \in\left\{V^{f}, B, D^{j}\right\}, f \in\{C, N C\}$ and $j \in\{H, F\}$, and the capital income taxes and negatively on the elasticity of asset substitution, $\sigma^{A}$.
} 
equity, which may encourage investors to increase the share of corporate equity in their portfolio. $^{14}$

Under the residence principle, a change in foreign capital income taxes has no direct effect on the portfolio holdings of domestic investors. ${ }^{15}$ The domestic investor's portfolio choice may, however, be indirectly affected by foreign capital income taxes via general equilibrium effects, which affect the gross rate of return of a foreign asset.

Given the investor's optimal portfolio choice, the optimal inter-temporal consumption pattern follows from maximizing the value function (1) subject to the inter-temporal budget constraint (2) and (6). The respective first-order conditions are

$$
\begin{array}{ll}
\frac{\partial U^{\star}(\cdot)}{\partial C_{t}}: & \frac{\partial U\left(A_{t+1}\right)}{\partial A_{t+1}}=u^{\prime}\left(C_{t}\right) \frac{1}{\rho} \frac{1+g}{1+\tau_{t}^{C}}, \\
\frac{\partial U^{\star}(\cdot)}{\partial A_{t}}: & \frac{\partial U\left(A_{t+1}\right)}{\partial A_{t+1}}=\frac{\partial U\left(A_{t+2}\right)}{\partial A_{t+2}} \frac{\rho \cdot\left(1+\bar{r}_{t+1}\right)}{1+g},
\end{array}
$$

which implies

$$
\frac{u^{\prime}\left(C_{t}\right)}{u^{\prime}\left(C_{t+1}\right)}=\frac{1+\tau_{t}^{C}}{1+\tau_{t+1}^{C}} \frac{\rho \cdot\left(1+\bar{r}_{t+1}\right)}{1+g}
$$

Assuming $u\left(C_{t}\right)=\frac{C_{t}^{1-1 / \sigma}}{(1-1 / \sigma)}$, where $\sigma$ denotes the inter-temporal elasticity of substitution, the optimal consumption is

$$
\begin{gathered}
\left(1+\tau_{t}^{C}\right) Q_{t}=\underbrace{\frac{\left(1+\tau_{t}^{C}\right)^{1-\sigma}}{\sum_{z=t}^{\infty}\left(1+\tau_{z}^{C}\right)^{1-\sigma} \prod_{u=t+1}^{z} \rho^{\sigma}\left(\frac{1+g}{1+r_{u}}\right)^{1-\sigma}}}_{m p c_{t}} T W_{t}, \quad \text { with } \\
T W_{t}=\left(1+\bar{r}_{t}\right) A_{t}+\underbrace{\sum_{z=t}^{\infty}\left\{\left(1-\tau^{L}\right) w_{z} l_{z}^{S}+T R_{z}-\left(1+\tau_{z}^{C}\right) \varphi\left(l_{z}^{S}\right)\right\} \prod_{u=t+1}^{z} \frac{1+g}{1+r_{u}}}_{H_{t}} .
\end{gathered}
$$

$m p c_{t}$ and $T W_{t}$ are the marginal propensity to consume and the total wealth. The latter consists of financial portfolio wealth, $\left(1+\bar{r}_{t}\right) A_{t}$, and human capital, $H_{t}$, net of the disutility of labour, $\varphi\left(l^{S}\right)$. Welfare is determined by the present value of the equivalent variation

$$
E V=T W\left(U_{1}, \bar{r}_{0}\right)-T W\left(U_{0}, \bar{r}_{0}\right) .
$$

(12) measures the differences in minimum expenditures with respect to the pre- and postreform utility levels, $U_{0}$ and $U_{1}$, applying pre-reform prices, that is, interest rates, $\bar{r}_{0}$. Since

\footnotetext{
${ }^{14}$ Differently, a more generous tax deduction for debt will most likely boost the supply of firm bonds and thus exert downward pressure on the gross rate of return of firm bonds. As a consequence, firm bonds become less attractive to investors and are substituted with different assets.

${ }^{15}$ Even if the foreign country levies withholding taxes on capital income, foreign taxes have no impact on the domestic investor's portfolio choice under the residence principle as long as the foreign withholding taxes are lower than the domestic taxes on capital income and the foreign tax payments are credited at home.
} 
the dynamic model accounts for the whole phase of transition, the equivalent variation refers to the present value of the resources that the household is willing to sacrifice to avoid the reform-induced change in prices.

The solution to the household's optimization problem additionally yields the first-order condition for the optimal labour supply, $l_{t}^{S}$, which depends on the labour and consumption taxes, $\tau^{L}$ and $\tau^{C}$, the wage rate, $w_{t}$, and the labour supply elasticity, $\varepsilon$,

$$
l_{t}^{S}=\gamma\left[\frac{\left(1-\tau^{L}\right)}{\left(1+\tau^{C}\right)} w_{t}\right]^{\varepsilon} .
$$

$\gamma$ represents a scaling parameter. The household supplies labour up to the point at which the marginal disutility arising from the labour supply, $\varphi\left(l_{t}^{S}\right)$, equals the net-of-tax compensation payment, that is, the net-of-tax wage income. ${ }^{16}$

$$
\varphi\left(l_{t}^{S}\right)=\frac{1-\tau^{L}}{1-\tau^{C}} w_{t} \quad \text { with } \quad \varphi\left(l^{S}\right)=\gamma^{-1 / \varepsilon} \frac{l^{1+1 / \varepsilon}}{(1+1 / \varepsilon)} .
$$

\section{The 2008 German Corporate Tax Reform}

To increase Germany's standing as an investment location, the core element of the 2008 German corporate tax reform entailed a cutback in the corporate tax rate of 10 percentage points from the initial 25 per cent to 15 per cent. In addition, the uniform trade tax measure was reduced from 5.0 to 3.5 per cent, which translated into a decline in the local business tax rate from the initial 16.7 per cent to 14.0 per cent. Taken together, the effective tax burden for corporations dropped from the initial 38.6 per cent to 29.8 per cent after the reform. ${ }^{17}$

Moreover, since 2009, any income from capital, including interest, dividends and capital gains, has been subject to a final withholding tax of 25 per cent, or effectively 26.4 (= $25 * 1.055)$ ) per cent when accounting for the solidarity surcharge of 5.5 per cent. Thereby, the introduction of the withholding tax resulted in substantial changes in personal capital income tax liabilities. While interest income was taxed as personal income facing a (top) personal income tax rate of 44.3 per cent before the reform, the withholding tax initiated a

\footnotetext{
${ }^{16}$ The aggregated labour supply is computed by $L_{t}^{S}=l_{t}^{S} \cdot N$, with $N$ representing the labour force.

${ }^{17}$ In addition, some base-broadening measures, such as an interest-stripping rule, to mention one of the most prominent modifications, have been enacted to limit tax-shifting activities by multinational enterprises. The interest-stripping rule limits the deduction of net interest expenses for tax purposes to 30 per cent of earnings before interest, taxes, depreciation and amortization (EBITDA) for companies with more than 3 (initially 1) million euros of net-interest expenses. The restricted deductibility of interest expenses carries over to the local trade tax, as well. Other base-broadening measures are the introduction of tightened loss carry-forward provisions and the abolition of the declining balance depreciation. We do not account for these measures in the current analysis.
} 
substantial tax relief of almost $18(44.3-26.4=17.9)$ percentage points in the top personal income tax bracket. Dividend income enjoyed preferential tax treatment, the so-called halfimputation system, until the end of 2008. Until then, only half of the earned dividend income was subject to the personal income tax, giving rise to an effective tax burden of only half of the (top) personal income tax, that is, $(44.3 / 2=) 22.2$ per cent. Under the withholding tax, dividend income is now taxed at effectively 26.4 per cent. Capital gains realized after a holding period of one year are referred to as non-speculative capital gains and were tax exempt before the 2008 reform. ${ }^{18}$ At the beginning of 2009, capital gains became fully subject to the withholding tax of 26.4 per cent. Since capital gains are taxed upon realization and not on an accrual basis, we follow the approach practised by the Ruding Committee (OECD 1991) and assume an (effective) tax rate of just 60 per cent of the statutory tax rate, that is, 15.8 per cent $(=0.6 * 25.0 * 1.055=15.8)$ for capital gains. The reduced tax rate reflects the tax advantage arising during the holding period of capital gains.

Last, at the beginning of 2007, the top personal income tax rate was increased by 3 percentage points from the initial 42.0 (44.3) per cent to 45.0 (47.5) per cent (inclusive of the solidarity surcharge). This measure explains the slight increase in the overall tax burden for non-corporate firms from 45.7 to 47.5 per cent during the analysed period.

Table 2: Statutory Tax Rates Before and After the 2008 Reform (in \%)

\begin{tabular}{|c|c|c|}
\hline & 2006 & 2009 \\
\hline Corporate Tax Rate & 25.0 & 15.0 \\
\hline Local Trade Tax Rate & 16.7 & 14.0 \\
\hline Tax Rate on Interest Income ${ }^{1)}$ & 44.3 & 26.4 \\
\hline Tax Rate on Dividend Income ${ }^{1)}$ & 22.2 & 26.4 \\
\hline Tax Rate on Capital Gains ${ }^{1)}$ & 0.0 & 15.8 \\
\hline Top Personal Income Tax Rate ${ }^{1)}$ & 44.3 & 47.5 \\
\hline Effective Tax Burden Corporations ${ }^{1), 2)}$ & 38.7 & 29.8 \\
\hline Effective Tax Burden Non-Corporate Firms ${ }^{1)}$ & 45.7 & 47.5 \\
\hline${ }^{1}$ Incl. the solidarity surcharge $;{ }^{2}$ Incl. the local tr & & \\
\hline
\end{tabular}

Table 2 summarizes the before- and after-reform tax rates. Before-reform tax rates refer to those effective in 2006, while after-reform rates show tax rates that are effective after 2009.

\footnotetext{
${ }^{18}$ Capital gains realized within the holding period of one year were also subject to the personal income tax.
} 


\section{Simulation Results}

The simulation results are grouped into three sections. First, we show the effect of the 2008 reform on the effective marginal tax rate and firms' cost of capital; second, we analyse the impact of the reform on the gross and net rates of return of the different kinds of assets; and third, we evaluate the ramifications of the reform for the macroeconomic equilibrium.

\subsection{Effective Marginal Tax Rate and Cost of Capital}

Table 3 shows the effective marginal tax rate $(\mathrm{EMTR})^{19}$ and the cost of capital $(\mathrm{CoC})^{20}$ before and after the 2008 reform. In addition, we decompose the EMTR into the effective marginal tax rate at the firm level (i.e. the investment tax wedge) and the effective marginal tax rate at the investor level (i.e. the savings tax wedge). The separation of the EMTR is particularly informative in the setting with international investors, in which the investment and savings decisions are decoupled.

Table 3: Effective Marginal Tax Rates and Cost of Capital

\begin{tabular}{|c|c|c|c|c|c|c|}
\hline \multirow{2}{*}{ All figures in \% } & \multicolumn{3}{|c|}{ Corporate Firms } & \multicolumn{3}{|c|}{ Non-Corporate Firms } \\
\hline & 2006 & 2009 & $\Delta(\% \mathrm{Pts})$ & 2006 & 2009 & $\Delta(\% \mathrm{Pts})$ \\
\hline \multicolumn{7}{|c|}{ Effective Marginal Tax Rate } \\
\hline Retained Earnings (RE) & 34.1 & 36.3 & +2.20 & - & - & - \\
\hline New Share Issues (NSI) & 48.7 & 44.2 & -4.50 & 41.6 & 52.3 & +10.7 \\
\hline Debt Financing (DF) & 40.1 & 20.5 & -19.6 & 42.9 & 20.0 & -22.9 \\
\hline Weighted Average ${ }^{1)}$ & 37.5 & 30.1 & -7.40 & 42.4 & 33.2 & -9.20 \\
\hline \multicolumn{7}{|l|}{ Cost of Capital } \\
\hline Retained Earnings (RE) & 12.3 & 12.7 & +0.42 & - & - & - \\
\hline New Share Issues (NSI) & 15.8 & 14.5 & -1.25 & 13.9 & 17.0 & +3.12 \\
\hline Debt Financing (DF) & 4.00 & 3.01 & -0.99 & 3.99 & 3.02 & -0.97 \\
\hline Weighted Av. ${ }^{1)}$ (short-run) $^{2)}$ & 9.02 & 8.74 & -0.28 & 8.04 & 8.74 & +0.70 \\
\hline Weighted Av. ${ }^{1)}$ (long-run) $^{2)}$ & 9.02 & 8.84 & -0.18 & 8.04 & 9.00 & +0.96 \\
\hline
\end{tabular}

${ }^{1)}$ Weights Corp.Firm: RE 52\%, NSI 6\% (EF 58\%), DF 42\%; Non-Corp.Firm: EF 41\%, DF 59\%;

2) Long-run (LR) variations include behavioural changes while short-run (SR) variations do not;

Source: Own calculations.

\footnotetext{
${ }^{19}$ The EMTR, $t^{e}$, measures the aggregated tax burden on the firm and the investor level. It is computed by the difference between the before-tax rate of return $u$ and the net-of- (firm and personal) tax rate of return $r$ in relation to the before-tax rate of return, that is $t^{e}=\frac{u-r}{u}$.

${ }^{20}$ The CoC denotes the before-tax rate of return an investment has to yield to remain profitable after taxation, to guarantee a net-of-tax rate of return equal to the market rate. While the effective marginal tax rate is solely composed of different tax rates, the $\mathrm{CoC}$ additionally hinges on the underlying market rate of return. Hence, the CoC may differ substantially across studies depending on the underlying market rate of return assumed.
} 
The figures for the EMTR and $\mathrm{CoC}$ in Table 3 are reported separately for the different methods of finance, comprising equity finance (EF) and external debt finance (DF). For corporations, equity finance is further differentiated into retained earnings (REs) and new share issues (NSIs). The weighted average of the EMTR and CoC is computed on the basis of the representative financial structure of the respective firm type, which is held constant in the case of the short-run (SR) calculation in the analysis. ${ }^{21}$ This approach allows us to isolate the impact arising from the changes in statutory tax rates. Adjustments in firms' behaviour (i.e. firms' financial structure) and the macroeconomic environment (i.e. interest rates) are only considered in the reported long-run (LR) changes for the CoC.

The effective tax burden of a corporate investment financed by retained earnings increases slightly, from 34.1 to 36.3 per cent, after the reform. This slight tax increase seems puzzling at first glance, given the major reduction in the corporate tax rate and in the local trade tax measure, but it is related to the introduction of the withholding tax, which more than outweighs the reduction in the corporate tax measures. If the investment is, however, financed by new share issues, the reduction in the corporate tax rate actually translates into a decline in the respective EMTR, which drops from 48.7 to 44.2 per cent. ${ }^{22}$ Despite this, new share issues remain the most expensive source of finance in absolute terms. The EMTR of the representative unincorporated firm rises by almost 11 percentage points in the case of equity finance. This outcome is explained by both the increase in the personal income tax rate in the analysed time period and the introduction of the withholding tax on capital income. The most striking result of Table 3 is the change in the EMTR under debt finance, which shows a huge decline of more than 20 percentage points for both firm types. Due to the introduction of the withholding tax, interest income is no longer subject to the personal income tax and thus the tax burden on this type of income declines from the initial 44.3 per cent to 26.4 per cent.

The changes in the CoC follow qualitatively the changes in the EMTR as the tax sensitivity of the cost of capital is identical to that of the EMTR. ${ }^{23}$ The substantial difference in the absolute size of the $\mathrm{CoC}$ under equity and debt finance is not tax driven. Instead, it refers to the underlying net-of-tax rate of return of the respective source of finance, which amounts to

\footnotetext{
${ }^{21}$ Following the empirical evidence for Germany (DAI 2004), we assume that the financial structure of the representative German corporation consists of 52 per cent retained earnings, 6 per cent new share issues and 42 per cent debt. The respective weights for the representative unincorporated German firm are 41 per cent equity finance and 59 per cent debt finance.

${ }^{22}$ The reduction in the EMTR was driven by the fact that the switch from the half-imputation system to the final withholding tax implied only a minor rise in the tax burden on dividend income relative to the major decline in the corporate tax rate.

${ }^{23}$ The cost of capital can be interpreted as a monotonic transformation of the EMTR of the type $1 /\left(1-t^{e}\right)$ which is multiplied by the net of tax return of the respective asset type.
} 
8.1 per cent in the case of equity finance and 2.4 per cent for debt finance. When comparing short- and long-run changes in the CoC for the two firm types, only small differences are found. This, however, does not mean that firms' behavioural adjustments considered in the long-run value of the $\mathrm{CoC}$ are negligible. In fact, the debt-asset ratio of the representative corporate firm increases by 4.76 per cent, but the higher indebtedness rises the costs of debt finance, which erode the tax advantage emerging from debt finance. ${ }^{24}$

The effective marginal tax rate at the firm level is defined by the ratio of the investment wedge and the before tax rate of return. ${ }^{25}$ Following the vast reduction in the statutory corporate tax rate, the local trade tax measure and the more favourable depreciation rule, the EMTR on the corporate firm level declines substantially from 34.0 to 24.3 per cent under equity finance. In the case of debt finance, this measure was already negative and becomes even more negative after the reform. The negative EMTR on the firm level resembles a quasitax subsidy, which arises from the full deductibility of the cost of debt finance combined with the generous tax depreciation scheme existent in Germany.

Table 4: Effective Marginal Tax Rates on the Firm Level and Investor Level

\begin{tabular}{lcccccc}
\hline \hline All figures in \% & \multicolumn{3}{c}{ Corporate Firms } & \multicolumn{3}{c}{ Non-Corporate Firms } \\
& 2006 & 2009 & $\Delta(\% \mathrm{Pts})$ & 2006 & 2009 & $\Delta(\% \mathrm{Pts})$ \\
\hline Effective Marginal Tax Rate on Firm Level & & & & \\
Equity Financing (EF) & 34.0 & 24.3 & -9.7 & 41.5 & 43.3 & +1.80 \\
Debt Financing (DF) & -7.47 & -7.94 & -0.47 & -7.73 & -7.57 & +0.16 \\
Weighted Average ${ }^{1)}$ & 16.6 & 10.8 & -5.8 & 12.5 & 13.3 & +0.80 \\
Effective Marginal Tax Rate on Investor Level & & & \\
Retained Earnings (RE) & 0.0 & 15.8 & +15.8 & - & - & - \\
New Share Issues (NSI) & 22.2 & 26.3 & +4.1 & 0.0 & 15.8 & +15.8 \\
Debt Financing (DF) & 44.3 & 26.3 & -18.0 & 44.3 & 26.3 & -18.0 \\
Weighted Average ${ }^{1)}$ & 18.6 & 20.5 & 1.90 & 23.5 & 21.3 & -2.20 \\
\hline 1) Weights Corp.Firm: RE 52\%, NSI 6\% (EF 58\%), DF 42\%; Non-Corp.Firm: EF 41\%, DF 59\%; \\
\hline \hline
\end{tabular}

Source: Own calculations.

The effective marginal tax rate at the investor level is defined by the ratio of the savings

\footnotetext{
${ }^{24}$ As outlined in the model description, debt finance incurs some extra costs since banks charge heavily indebted firms higher fees to compensate for the higher risk of default associated with a larger debt-asset ratio.

${ }^{25}$ The investment wedge, $u-i$, is defined by the difference between the before-tax rate of return $u$ and the market rate of return $i$. Thus, the EMTR at the firm level takes the form $t^{I}=\frac{u-i}{u}$. A high EMTR at the firm level implies that a higher before-tax rate of return is also required to guarantee that the investment yields a competitive net-of-firm tax rate of return.
} 
wedge and the after-personal-tax rate of return of the investment. ${ }^{26}$ It becomes obvious from Table 4 that the EMTR at the investor level corresponds to the effective tax burden on capital gains, dividend income and interest income, respectively. The ex-ante untaxed capital gains face a major tax hike when the withholding tax on capital income is introduced. ${ }^{27}$ Differently, the switch from the half-imputation system to the withholding tax results in only a slight increase in the tax burden on dividend income, amounting to 4 percentage points. The substantial tax relief on interest income originates from the replacement of the personal income tax with the withholding tax.

The change in the weighted average of the EMTR on the corporate firm level reveals that the 2008 reform provoked a non-negligible reduction ( -5.8 percentage points) in the effective tax burden for corporations. From a theoretical point of view, this tax relief should have the potential to stimulate corporate investments. Our simulation results, however, do not confirm this conjecture. The explanation for why corporate investment stay behind is given by the change in the EMTR at the investor level. The introduction of the withholding tax caused a substantial rise in the savings tax wedge on corporate equity holdings, while at the same time the savings tax wedge on interest income was significantly lowered. Thus, the reform initiated a tax discrimination of equity holdings vis-'à-vis interest-bearing titles (bonds). As a consequence, domestic investors become reluctant to hold corporate equity in their portfolio, which negatively affects corporate investment activity.

\subsection{Rates of Return and Investors' Portfolio Composition}

To gain insights into the incidence of capital income taxes on portfolio investments, we report in Table 5 the reform-induced changes in the gross and net rates of return of the different assets and households' portfolio composition.

For an investor in the top income tax bracket, the introduction of the withholding tax implied a reduction in the effective tax burden on interest income of approximately 18 percentage points. In response to the vast tax relief, the short-run net-of-tax returns on interest-bearing firm and government bonds jumped from 2.40 to 3.17 per cent and from 2.06 to 2.72 per cent, respectively. In the long run, the net-of-tax returns of firm and government bonds deteriorate steadily due to the growing supply of these bonds. As depicted on the last line of Table 5,

\footnotetext{
${ }^{26}$ The EMTR on the investor level is given by $t^{S}=\frac{i-r}{i}$, with $i-r$ denoting the savings wedge, that is, the difference between the market rate of return, $i$, and the after-personal-tax rate of return, $r$. For a given market rate of return, a higher effective marginal tax rate at the investor level implies a lower net-of-personal-tax rate of return for the investor.

${ }^{27}$ In line with the OECD (1991), we assume an (effective) tax rate of just 60 per cent of the statutory tax rate for capital gains, that is 15.8 per cent $(0.6 * 25.0 * 1.055=15.8)$, reflecting the tax advantage of capital gains during the holding period.
} 
the supply of these two bond types increases by 15.4 and 12.8 per cent, respectively. Despite the significant supply effect, the long-run net-of-tax returns of firm and government bonds remain about 20 per cent higher relative to the initial values.

In contrast to the pronounced changes in the net-of-tax return of interest-bearing assets, the change in the net-of-tax return of firm equity appears to be almost negligible. Nevertheless, it is noteworthy that the net return on firm equity rose after the reform, despite the flattened portfolio demand caused by the higher savings tax wedge. On the one hand, the return increase is driven by the major reduction in the corporate tax rate, which induced a slight drop in the overall EMTR (i.e. the combined investment and savings wedge) on firm equity. On the other hand, the relatively strong contraction in the volume of firm equity (-6.7 per cent in the short run) caused the gross rate of return of this asset to climb by 12.6 per cent in the short run. Even though the contractive effect becomes weaker over the course of time, the gross rate of return on firm equity is still about 8 per cent above its initial value in the long run.

Table 5: Rates of Return, Asset Volumes and Portfolio Shares

\begin{tabular}{|c|c|c|c|c|c|}
\hline & $\begin{array}{l}\text { Firm } \\
\text { Bonds }\end{array}$ & $\begin{array}{l}\text { Dom.Gov. } \\
\text { Bonds }\end{array}$ & $\begin{array}{l}\text { For.Gov. } \\
\text { Bonds }\end{array}$ & $\begin{array}{l}\text { Firm } \\
\text { Equity }\end{array}$ & $\begin{array}{l}\text { Av.PF } \\
\text { Return }\end{array}$ \\
\hline \multicolumn{6}{|l|}{ Net Return $^{1)}$} \\
\hline Initial Value & 2.40 & 2.06 & 2.06 & $8.10^{3)}$ & 5.46 \\
\hline Short-Run Value & $3.17(+32.1)$ & $2.72(+32.0)$ & $2.72(+32.0)$ & $8.48(+4.69)$ & $5.73(+4.95)$ \\
\hline Long-Run Value & $2.87(+19.6)$ & $2.47(+19.9)$ & $2.62(+27.2)$ & $8.14(+0.50)$ & $5.46(+0.00)$ \\
\hline \multicolumn{6}{|l|}{ Gross Return $^{1)}$} \\
\hline Initial Value & 4.30 & 3.70 & 3.70 & 10.1 & 7.33 \\
\hline Short-Run Value & $4.24(-1.40)$ & $3.61(-2.43)$ & $3.65(-1.35)$ & $11.4(+12.6)$ & $7.79(+6.28)$ \\
\hline Long-Run Value & $3.89(-9.54)$ & $3.36(-9.19)$ & $3.55(-4.05)$ & $10.9(+8.14)$ & $7.34(+0.14)$ \\
\hline \multicolumn{6}{|l|}{ Portfolio Share ${ }^{2)}$} \\
\hline Initial Value & 15.8 & 6.95 & 21.8 & 55.4 & 100 \\
\hline Short-Run Value & $17.3(+9.25)$ & $7.23(+4.03)$ & $23.0(+5.27)$ & $52.5(-5.23)$ & 100 \\
\hline Long-Run Value & $17.2(+8.74)$ & $7.38(+6.19)$ & $24.5(+12.3)$ & $50.9(-8.14)$ & 100 \\
\hline \multicolumn{6}{|l|}{ Asset Volume } \\
\hline Short-Run Change ${ }^{2)}$ & 7.57 & 2.50 & 3.66 & -6.68 & - \\
\hline Long-Run Change ${ }^{2)}$ & 15.4 & 12.8 & 19.2 & -2.52 & - \\
\hline $\begin{array}{l}\text { 1) All figure refer to real } r \\
\text { 3) The figure denotes the } \\
\text { companies assuming an a } \\
6.5 \text { and } 9.6 \text { for the geome }\end{array}$ & tes of return & Changes in $p$ & nt are repc & in brackets. & $\begin{array}{l}\text { In per cent } \\
\text { aAX-listed } \\
\text { lues between }\end{array}$ \\
\hline
\end{tabular}

Source: Own calculations. 
Table 5 provides insights into the tax driven portfolio adjustments of domestic investors. Given the major increase in the net-of-tax rates of return on interest-bearing assets, it becomes straight forward that the respective portfolio share increased disproportionally. The quantity of firm and domestic (foreign) government bonds added to the portfolio amount to 8.7 and 6.2 (12.3) per cent, in the long run, while the amount of firm equity drops by more than 8 per cent. ${ }^{28}$

The important insight gained from Table 5 is that the 2008 reform encouraged investors to restructure their portfolio in favour of interest-bearing assets at the expense of firm equity. Put differently, the 2008 reform created a tax-induced reluctance on the part of domestic investors to hold corporate equity, which would most likely create a lack of investment funds and thus impede the investment activity of corporate firms, as we infer from Table 6.

To check the robustness of our results, we re-ran the simulations using a 5 per cent higher and lower elasticity of asset substitution. The sensitivity analysis (see Appendix A for details) shows that the long-run values for the net and gross rates of return of the different assets reported in Table 5 vary only at the second decimal place.

\subsection{National Investors Only - No Foreign Firm Ownership}

When analysing the ramifications of the German 2008 reform for growth and welfare, we start with the counterfactual scenario in which all domestic firms are home-owned, that is, owned by domestic investors. The analysis serves as a point of comparison for the simulation results in Section 5.4 and to highlights the role of foreign firm ownership, meaning international investors, in the reform outcome.

Most strikingly, the results in Table 6 reveal a substantial slump in the economic activity of corporate firms following the reform. In the long run, the output in this sector declines by more than 0.4 per cent and gross investment and employment drop by 0.24 and 0.67 per cent, respectively. This outcome seems paradoxical at first glance, given the major reduction in the corporate tax burden (i.e. the investment tax wedge) following the reform. The rationale behind the finding refers to the tax-motivated portfolio choice of domestic investors analysed above. Due to the introduction of the withholding tax, interest-bearing assets benefit from a substantial tax reduction, while the tax burden on corporate equity increases. As a response to the differentiated tax treatment, domestic investors sell off their corporate equity holdings and thereby not only impede the economic activity but even challenge disinvestments in this

\footnotetext{
${ }^{28}$ Note that all the reported variations in portfolio holdings originate solely from tax-induced portfolio optimization but do not reflect any diversification or risk-adjustment motives.
} 
sector. $^{29}$

Table 6: 2008 Reform, National Investors Only

\begin{tabular}{lccc}
\hline \hline All figures in \% & Total & $\begin{array}{c}\text { Corporate } \\
\text { Firm }\end{array}$ & $\begin{array}{c}\text { Non-Corporate } \\
\text { Firm }\end{array}$ \\
\hline Production (GDP) & +0.508 & -0.425 & +2.240 \\
Gross Investment & +1.002 & -0.236 & +3.677 \\
Employment & +0.258 & -0.686 & +2.069 \\
$\quad$ Low skilled & +0.686 & -0.181 & +2.708 \\
$\quad$ Medium skilled & +0.653 & -0.357 & +2.528 \\
$\quad$ High skilled & -2.047 & -3.168 & -0.365 \\
Debt-Equity Ratio & - & +4.516 & +2.548 \\
HH Consumption ${ }^{1)}$ & $-2.464 /+1.383$ & & \\
Tax Revenues & (1) & $-10.70 /+6.922$ & \\
Welfare & $-0.509 /-0.857$ & \\
\hline${ }^{1)}$ short-/long-run changes; ${ }^{2)}$ in Bn. Euro; ${ }^{3)}$ in \% of GDP / wealth of HH \\
\hline \hline
\end{tabular}

Source: Own calculations.

Despite the contraction in the corporate sector, the reform nevertheless stimulates economywide investments $(+1.00$ per cent $)$ and employment $(+0.26$ per cent $)$ and thereby the total output $(+0.51$ per cent). The positive stimulus is triggered by the increased economic activity in the non-corporate sector, which is stimulated by the relatively larger reduction in the EMTR of non-corporate firms (-9.2 percentage points) vis-à-vis corporate firms (-7.4 percentage points, see also Table 3 ). In addition, the reform reduced the savings tax wedge for non-corporate firm equity. Thus, the tax motive to sell off the equity of unincorporated firms is much smaller than that for corporate firm equity. Hence, investors are willing to keep their holdings of unincorporated firm equity and thereby do not impede the investments in this sector. In the long-run equilibrium, investment and employment in the non-corporate sector increase by 3.7 and 2.1 per cent, respectively, leading to a rise in the sector-specific GDP of 2.2 per cent. ${ }^{30}$

The transition phase to the long-run equilibrium is marked by a significant increase in the debt-equity ratio of corporate and non-corporate firms, which jumps up by 4.5 and 2.6 per cent, respectively. The adjustment in the firms' financial behaviour is caused by the lower cost of debt finance in the new steady-state equilibrium (see Table 5). The latter is characterized by an increased supply of firm bonds ( +15.4 per cent in the long run) and a

\footnotetext{
${ }^{29}$ In the long run, the portfolio share of corporate equity holdings is reduced by more than 8 per cent after the 2008 reform was implemented (see Table 5).

${ }^{30}$ The increase in the investment activity of non-corporate firms seems to be quite large at first glance. Non-corporate firms, however, account for less than $1 / 3$ of the total German economy.
} 
substantially lower gross rate of return on firm bonds (-9.5 per cent).

The change in the skill composition of the labour force is driven by the increase in the top personal income tax rate, which pushes back the labour supply of the highly skilled by almost 2 per cent. The drop in the high skilled labour supply particularly affects corporate firms (2.92 per cent) in relation to unincorporated firms (-0.45 per cent). In aggregate, employment nevertheless increases marginally after the reform due to the stimulated economic activity in the non-corporate sector.

Households' consumption pattern is subject to a major variation during the phase of transition. Household consumption decreases by 2.5 per cent in the short run, while the expansion of the economic activity during the phase of transition increases household consumption by 1.4 per cent in the long run. Households' consumption pattern plays a crucial role in the welfare implication of the reform. The latter is measured by the present value of the equivalent variation. Due to discounting, any reduction in short-run consumption implies a stronger negative impact on welfare compared with the positive effect arising from an equally sized increase in long-run consumption. Accordingly, the 2.5 per cent decrease in short-run household consumption dominates the overall welfare effect and signs it negative. ${ }^{31}$ Welfare, expressed as a fraction of GDP, shrinks by 0.51 per cent due to the reform. If welfare is expressed in terms of household wealth, the welfare loss associated with the reform amounts to 0.86 per cent of household wealth, that is, the wealth of German households diminished by 0.86 per cent due to the introduction of the 2008 German corporate tax reform.

Lastly, in the counterfactual scenario, the fiscal costs of the reform amount to about 10.7 billion euros in the short run. In the long run, additional tax revenues of almost 7 billion euros can potentially be collected.

\subsection{The Role of International Investors (Foreign Firm Ownership)}

The increasing economic and financial integration within the euro area has led to a significant reduction in the home bias within most European economies. For the German case, the share of domestic assets held by national investors amounted to about 79 per cent at the time of euro creation (in 1999) and steadily declined thereafter to approximately 58 per cent in 2007 (German Central Bank 2008). With regard to German firm equity, a similar trend of internationalization of the ownership structure is observed. Back in 1999, foreign investors' participation in domestic firms amounted to just 19 per cent, but increased over the course

\footnotetext{
${ }^{31}$ The magnitude of the welfare effect additionally depends on the applied value of the elasticity of intertemporal substitution. The lower the value of the elasticity, the less negative is the welfare implication of the analysed reform (see also the sensitivity analysis in Appendix A).
} 
of time to about 40 per cent in 2007 (German Central Bank 2008). In terms of market capitalization, the share of foreign investors participating in German listed corporations amounts to about one-third (in 2007) and is thus slightly lower than the above figure.

The lion's share of foreign investors holding German assets is predominantly located within the euro area which has an important implication for the tax treatment of these investors. In essence, all German double taxation agreements follow closely the OECD Model Tax Convention on Income and on Capital (OECD 2010), which stipulates that business profits are taxed at source (source principle), while capital income is subject to taxation in the residence country of the foreign investor (residence principle). Nevertheless, every European country is eligible to levy a source-based withholding tax on capital income within certain thresholds. ${ }^{32}$ By way of derogation from the double taxation agreements, the European Parent-Subsidiary Directive (Council Directive 2003/123/EC and 2011/96/EU) and the European Interest-and-Royalty Directive (Council Directive 2003/49/EC and COM/2011/714/FINAL) grant European investors extensive tax privileges up to complete exemption from withholding taxes, if the investor (i.e. the holding company) owns a stake of at least $10 \%$ of the dividendor royalty-paying firm. ${ }^{33}$ Thus, international investors largely face privileged tax treatment vis-à-vis national investors.

In reference to the institutional background, we calibrate the participation share of foreign investors in domestic firms to 40 per cent and assume, in accordance with Mintz and Weichenrieder (2010), that these foreign investors are exempt from withholding taxes on capital income since they either reside in the euro area, are of an institutional type, or are located in low-tax jurisdictions (tax havens). Thus, the participation of international investors in domestic firms brings about a significant dilution of the savings tax wedge and the EMTR for jointly (domestically and foreign) held corporations. This matter of fact alters the simulation results substantially. With no international investors considered (see Table 6), the corporate sector faces a distinct contraction after the 2008 reform. Contrary to that, when international investors are considered, the corporate investment and sectoral output rise by 0.62 and respectively 0.03 per cent, as reported in Table 7 .

Despite the moderate investment impulse in the corporate sector, the long-run change

\footnotetext{
${ }^{32}$ In general, withholding taxes on dividends shall not exceed 15 per cent (standard case) or 5 per cent in the case that the beneficial owner is a company that holds at least 25 per cent of the capital of the company paying the dividend (OECD 2010, Article 10). Further, withholding taxes on interest income shall not exceed 10 per cent and capital gains shall only be subject to taxation in the residence country of the investor.

${ }^{33}$ The Parent-Subsidiary Directive stipulates that profit distributions (dividends) between parent companies and subsidiaries (both based in European member states) shall be exempted from withholding tax in the case that the parent company holds at least $10 \%$ of the shares of the subsidiary company paying the dividends. The Interest-and-Royalty Directive defines the exemption of interest and royalty payments between affiliated European companies holding at least a $10 \%$ stake.
} 
in sectoral employment remains negative (-0.46 per cent). This outcome originates from the stark decline in the high-skilled labour supply after the rise in the top personal income tax rate. The negative employment effect additionally explains the very low rise in sectoral output. For non-corporate firms, the simulation results are qualitatively identical to the outcome reported in the scenario with no international investors in Table 6. This is due to the fact that international ownership is limited to corporate equity in the analysis.

Table 7: 2008 Reform, Foreign Firm Ownership: 40\%

\begin{tabular}{|c|c|c|c|}
\hline all figures in $\%$ & Total & $\begin{array}{l}\text { Corporate } \\
\text { Firm }\end{array}$ & $\begin{array}{c}\text { Non-Corporate } \\
\text { Firm }\end{array}$ \\
\hline Production (GDP) & +0.840 & +0.025 & +2.352 \\
\hline Gross Investment & +1.761 & +0.619 & +4.227 \\
\hline Employment & +0.369 & -0.457 & +1.954 \\
\hline Low skilled & +0.794 & +0.031 & +2.574 \\
\hline Medium skilled & +0.765 & -0.124 & +2.415 \\
\hline High skilled & -1.934 & -2.921 & -0.453 \\
\hline Debt-Equity Ratio & - & +4.584 & +2.655 \\
\hline HH Consumption ${ }^{1)}$ & $-3.883 /+1.043$ & & \\
\hline Tax Revenues ${ }^{1), 2)}$ & $-30.50 /-7.199$ & & \\
\hline Welfare $^{3)}$ & $-1.072 /-1.802$ & & \\
\hline
\end{tabular}

Source: Own calculations.

In summary, the simulation results in Table 7 show a larger growth effect due to the 2008 reform, if international investors are considered. The total investment increases by 1.76 instead of just 1.00 per cent, employment rises by 0.37 instead of 0.26 per cent and consequently the overall output growth amounts to 0.84 instead of 0.51 per cent. Paradoxically, the larger economic growth does not coincide with enhanced domestic welfare. The stronger erosion of the tax base in the presence of tax-privileged international investors increases the financing cost of the reform and thus a larger amount of lump-sum transfers from households is required to balance the government budget. In response, households' short-run consumption falls by -3.88 instead of -2.46 per cent and the long-run recovery of consumption possibilities amounts to +1.04 instead of +1.38 per cent. The substantially larger drop in short-run consumption explains the more negative welfare effect of the reform with foreign firm ownership. Our measure of welfare, the present value of the equivalent variation in relation to GDP (household wealth), falls by 1.07 (1.80) per cent if international investors are considered, but it declines by just $0.51(0.86)$ per cent in the counterfactual analysis with no international investors (see 
Table 6). Thus, the role of international investors appears to be twofold and is a blessing and a curse at the same time. On the one hand, the participation of foreign investors in domestic firms fosters corporate investment and thereby economic growth. On the other hand, the larger growth effect triggered by the reform results in a more negative welfare outcome.

From a theoretical point of view, the presence of international investors in jointly held firms dilutes the savings tax wedge and thus the EMTR on the investor level. In combination with the reform induced reduction in the investment tax wedge (i.e. the EMTR on the firm level), the investment activity of jointly held firms is stimulated by the reform. Contrary to that, purely domestically owned corporations are fully harmed by the reform, because they cannot bypass the shift of the capital tax burden from the firm to the household level, which manifests in an impediment to their investment activity (see Table 6). The negative welfare outcome originates from the exemption of international investors from the withholding tax on capital income, which erodes the respective domestic tax base. In total, the negative tax base effect associated with tax-privileged foreign investors weighs much more strongly than a moderate investment stimulus. Thus, the total financing cost of the reform increase and restrict households' consumption possibilities which, signals a stronger negative welfare effect compared with the outcome of the counterfactual analysis in which no international investors are considered.

To gain a deeper understanding of the role of international investors in the growth and welfare effects of the 2008 reform, we conduct a sensitivity analysis with regard to the share of foreign firm ownership. The results are presented in Table 8. In line with the above discussion, the growth effect initiated by the reform turns out to be significantly lower, and, conversely, the welfare effect of the reform becomes less negative, if the share of foreign firm ownership is reduced to an exogenous value of 30 or 20 per cent, respectively. The mechanism explaining the outcome refers again to the relative importance of international investors in diluting the savings tax wedge, that is, the EMTR at the investor level. If the participating share of international investors in domestic firms, i.e. foreign firm ownership, is small, the tax-induced portfolio choice of domestic investors creates a severe shortage of corporate investment funds and thus impedes the investment activity of these firms. If the share of tax-privileged foreign investors increases, the financing frictions for corporate firms are relaxed, allowing the investment stimulus brought about by the reform to unfold. The dark side of the larger growth effect appears, however, in the form of a more negative welfare outcome. The tax privilege given to international investors erodes the domestic capital income tax base and thus elevates the cost of the reform substantially. The need to balance 
the government budget in turn constraints household consumption, which causes the negative welfare outcome.

Since the adjustment in the share of foreign firm ownership is determined endogenously in the model, we find that the variation of this share is larger the lower its initial value. For instance, if the initial share of foreign firm-ownership is set to 20 per cent, the endogenous increase in this variable amounts to 2.48 per cent, while it is only 1.57 (1.11) per cent if the initial share of foreign firm-ownership is set to 30 (40) per cent. This result is explained by the general equilibrium effects, which are more pronounced the larger the pre-existing imbalances. Here the pre-existing imbalances refer to the financial constraints for corporate investment activities arising from the tax-induced portfolio choice of domestic investors.

Table 8: 2008 Reform, Foreign Firm Ownership: 30\% and 20\%

\begin{tabular}{|c|c|c|c|c|c|c|}
\hline \multirow[b]{2}{*}{ all figures in $\%$} & \multicolumn{3}{|c|}{$30 \%$ Foreign Ownership } & \multicolumn{3}{|c|}{ 20\% Foreign Ownership } \\
\hline & Total & $\begin{array}{l}\text { Corp. } \\
\text { Firm }\end{array}$ & $\begin{array}{l}\text { NC- } \\
\text { Firm }\end{array}$ & Total & $\begin{array}{l}\text { Corp. } \\
\text { Firm }\end{array}$ & $\begin{array}{l}\text { NC- } \\
\text { Firm }\end{array}$ \\
\hline Production (GDP) & +0.737 & -0.115 & +2.318 & +0.644 & -0.240 & +2.288 \\
\hline Gross Investment & +1.525 & +0.352 & +4.058 & +1.313 & -0.114 & +3.905 \\
\hline Employment & +0.334 & -0.529 & +1.991 & +0.303 & -0.592 & +2.023 \\
\hline Debt-Equity Ratio & - & +4.593 & +2.649 & - & +4.581 & +2.625 \\
\hline HH Consumption ${ }^{1)}$ & \multicolumn{3}{|c|}{$-3.501 /+1.141$} & \multicolumn{3}{|c|}{$-3.124 /+1.233$} \\
\hline Tax Revenues ${ }^{1), 2)}$ & \multicolumn{3}{|c|}{$-25.14 /-3.385$} & \multicolumn{3}{|c|}{$-19.80 /+0.445$} \\
\hline Welfare $^{3)}$ & \multicolumn{3}{|c|}{$-0.928 /-1.561$} & \multicolumn{3}{|c|}{$-0.780 /-1.312$} \\
\hline \multicolumn{7}{|c|}{${ }^{1)}$ short-/long-run changes; $\left.{ }^{2}\right)_{\text {in Bil. Euro; }}{ }^{3}$ in $\%$ of GDP / wealth of HH } \\
\hline
\end{tabular}

Source: Own calculations.

We additionally conduct sensitivity analyses with regard to the elasticity of inter-temporal substitution and the elasticity of asset substitution (see Appendix A). For a higher (lower) value of the elasticity of inter-temporal substitution (Table 11), we find that the welfare measure becomes more negative (positive). This is due to the stronger (weaker) reaction in households' consumption expenditures to the larger financing costs of the reform (since the government's budget is balanced by lump-sum transfers at the margin).

In the case of a higher (lower) value for the elasticity of asset substitution (Table 9), we find a higher (lower) level of disinvestments in the corporate sector. Additionally, corporations respond with a stronger adjustment in their financial behaviour as reflected by a substantial increase (decrease) in their debt-asset ratio. A higher (lower) degree of substitutability between assets implies more (less) pronounced portfolio adjustments and thus the lack of corporate investment funds becomes more (less) severe. 


\section{Conclusion}

Even though the 2008 German corporate tax reform brought about a considerable reduction in the tax burden for corporations, the simulation results reveal only a relatively poor growth stimulus after the reform. The explanation for this finding refers to the reform-induced increase in the capital income tax burden on the investors' level. The latter triggers a taxmotivated adjustment of portfolio investments by domestic investors, which, in turn, creates a severe lack of corporate investment funds and hence impedes the investment activity of those firms. The negative effect of the tax-induced portfolio shift is, however, diluted if foreign firm ownership, meaning the participation of international investors in domestic firms, is considered. The existence of tax-privileged international investors enables the growth stimulus brought about by the considerable reduction in the corporate tax burden to unfold. One downside associated with the tax-privileged international investors is the erosion of the domestic capital income tax base and the resulting rises in the financing cost of the reform, which affects domestic welfare negatively. The erosion of the domestic capital income tax base is additionally magnified by the tax-motivated portfolio shift of domestic investors.

The implication for policy advice arising from our analysis is two fold. First, households, which have so far often been perceived as rather immobile, face an increased number of possibilities for tax avoidance in a world of integrated capital markets. Hence, the repercussions arising from households' tax-motivated portfolio choice need to be taken into account by policy makers when designing tax reforms. Unfortunately, this issue is hardly recognized, even by the existing literature, which predominantly focuses on the base erosion through the profit shifting of firms. ${ }^{34}$ Second, a tax-induced growth stimulus can become very costly in a world of integrated capital markets, particularly if the tax reduction attracts tax-privileged foreign investors, who intensify the erosion of the domestic tax bases even further - an outcome that is most valid under the residence principle.

\section{References}

[1] Auerbach, A.J. (1979): "Wealth Maximization and the Cost of Capital", Quarterly Journal of Economics 93/3, 433-446.

[2] Bradford, D.F. (1981): "The Incidence and Allocation Effects of a Tax on Corporate Distributions", Journal of Public Economics 15/1, 1-22.

[3] Deutsches Aktieninstitut (DAI), (2004): DAI-Factbook, Frankfurt am Main.

\footnotetext{
${ }^{34}$ See for instance Dharmapla (2014) for an overview of the recent empirical literature on base erosion and profit shifting.
} 
[4] DeMooij, R.A. and M.P. Devereux (2011): "An applied analysis of ACE and CBIT reforms in the EU", International Tax and Public Finance 18/1, 93-120.

[5] Destatis, German Statistical Office (2008): Statistisches Jahrbuch 2008 für die Bundesrepublik Deutschland, Wiesbaden.

[6] Devereux, M. (2000): "Issues in the taxation of income from foreign portfolio and direct investment", in: Cnossen, S. (ed.) Taxing capital income in the European Union, Oxford University Press, pp. 110-134.

[7] Devereux, M. (2004): "Some Optimal Tax Rules for International Portfolio and Direct Investment", Finanzarchiv, 60/1 pp. 1-23.

[8] Dharmapala, D. (2014): "What Do We Know about Base Erosion and Profit Shifting? A Review of the Empirical Literature", Fiscal Studies 35, 421-448.

[9] Dietz M. and C. Keuschnigg (2004): "Corporate Income Tax Reform in Switzerland", Swiss Journal of Economics 140, 483-519.

[10] Dietz, M. and C. Keuschnigg (2007): "A Growth Oriented Dual Income Tax", International Tax and Public Finance 14/2, 191-221.

[11] European Union (2003, 2011), Council Directive 2003/49/EC, COM/2011/714/FINAL, on a common system of taxation applicable to interest and royalty payments made between associated companies of different Member State.

[12] European Union (2003, 2011), Council Directive 2003/123/EC, 2011/96/EU on the common system of taxation applicable in the case of parent companies and subsidiaries of different Member States.

[13] Finke, K., J.H. Heckemeyer, T. Reister and C. Spengel (2010): "Impact of Tax Rate Cut Cum Base Broadening Reforms on Heterogeneous Firms - Learning from the German Tax Reform 2008", Oxford University Centre for Business Taxation Working Paper 10/05.

[14] Fuest, C. and B. Huber (2000): "Can corporate-personal tax integration survive in open economies? Lessons from the German tax reformtextquotedblright, FinanzArchiv: Public Finance Analysis, 57, 514-524.

[15] German Central Bank (2008): "Das deutsche Auslandsvermögen seit Beginn der Währungsunion: Entwicklung und Struktur", Monatsbericht Oktober 2008, Frankfurt Main.

[16] Gordon, R.H. and V. Gaspar (2001): "Home Bias in Portfolios and Taxation of Asset Income", The B.E. Journal of Economic Analysis \& Policy 1, 1-28.

[17] Gordon, R.H. and J.R. Hines (2002): "International Taxation", in A.J. Auerbach and M. Feldstein (eds.) Handbook of Public Econommics, Vol. 4, Elsevier, pp.1935-1995.

[18] Haufler, A. (1999): "Prospects for Co-ordination of Corporate Taxation and the Taxation of Interest Income in the EU", Fiscal Studies, 20, pp. 133-153.

[19] Huzinga, H. and S.B. Nielsen (1997): "Capital income and profit taxation with foreign ownership of firms", Journal of International Economics, 42, pp. 149-165. 
[20] Huzinga, H. and S.B. Nielsen (2002): "The coordination of capital income and profit taxation with cross-ownership of firms", Regional Science and Urban Economics, 32, pp. $1-26$.

[21] Keen, M. and K.A. Konrad (2013) "The theory of international tax competition and coordination", in Auerbach, A. J., Chetty, R., Feldstein, M. und Saez, E. (Edts), Handbook of Public Economics, Vol. 5. Amsterdam \& Oxford, Elsevier, 257-328.

[22] Kotlikoff, L.J. and L.H. Summers (1987): "Tax Incidence "in A.J. Auerbach and M. Feldstein (eds.) Handbook of Public Econommics, Vol. 2, Elsevier, Chapt. 16.

[23] Mendoza, E.G. and L.L. Tesar (1998): "The International Ramifications of Tax Reforms: Supply-Side Economics in a Global Economy", American Economic Review 88/1, 226245.

[24] Mintz, J.M. and A.J. Weichenrieder (2010): The Indirect Side of Direct Investments: Multinaitonal Company Finance and Taxation, MIT Press, Cambridge, MA.

[25] OECD (1991): Taxing Profits in a Global Economy: Domestic and International Issues, OECD Publishing.

[26] OECD (2010): Model Tax Convention on Income and on Capital 2010: Full Version, OECD Publishing.

[27] Peichl, A. (2008): "The Benefits of Linking CGE and Microsimulation Models: Evidence from a Flat Tax Analysis", IZA Discussion Paper No. 3715.

[28] Pfaffermayr, M., Stöckl, M., and H. Winner (2013): "Capital Structure, Corporate Taxation and Firm Age", Fiscal Studies, 34, pp.109-135.

[29] Radulescu, D. and M. Stimmelmayr (2010): "The impact of the 2008 German corporate tax reform: A dynamic CGE analysis", Economic Modelling 27/1, 454-467.

[30] Sinn, H.-W. (1991): "Taxation and the Cost of Capital: The 'Old' View, the 'New' View, and Another View" in: D. Bradford, (ed.) Tax Policy and the Economy 5, 25-54.

[31] Sinn, H.-W. (2003): The New Systems Competition, Wiley-Blackwell.

[32] Slemrod, J., Alworth, J., Deveruex M.P., Gordon, R.H., Huizinga, H. and Vann, R. (1996): The Taxation of Income from International Investors, Paris: Organization for Economic Cooperation and Development (OECD).

[33] Sørensen, P. B. (2001): OECDTAX: A Model of Tax Policy in the OECD Economy, Technical Working Paper, University of Copenhagen.

[34] Sørensen, P. B. (2002): "The German Business Tax Reform of 2000: A Gernal Equilibrium Analysis" German Economic Review 3, 347-378.

[35] Stehle, R. (1999): "Renditevergleich von Aktien und festverzinslichen Wertpapieren auf Basis des DAX und des REXP", Humboldt-Universität zu Berlin.

[36] Stimmelmayr, M. (2007): Fundamental Capital Income Tax Reforms: Discussion and Simulation using ifoMOD, Mohr Siebeck, Tübingen. 


\section{Appednix}

\section{A Sensitivity Analyses}

To check the robustness of the analysed growth and welfare effects brought about by the 2008 German corporate tax reform, we conduct a series of sensitivity analyses with regard to two behavioural key elasticities: the elasticity of asset substitution (see Table 9 and Table 10) and the elasticity of inter-temporal substitution (Table 11).

\section{A.1 Elasticity of Asset Substitution}

Table 9 reports the short- and long-run impacts of the 2008 German corporate tax reform on the rates of return of the different assets, domestic investors' portfolio holdings and the change in asset volumes in the case of a 5 per cent higher and lower elasticity of asset substitution. A higher (lower) value of the respective elasticity results in larger (smaller) variation in asset volumes and thereby the tax-induced portfolio adjustments become more (less) pronounced, as well. When comparing the simulation outcomes under the different values of the elasticity of asset substitution, we find only minor discrepancies (smaller than 1 per cent). Only in the case of the long-run changes in asset volumes do the simulation results deviate by a magnitude of about 5 per cent. Nevertheless, the simulation outcome seems robust with regard to the variation in the elasticity of asset substitution.

Table 9: Rates of Return, Asset Volumes and Portfolio Shares

\begin{tabular}{|c|c|c|c|c|c|c|c|c|c|c|}
\hline & \multicolumn{5}{|c|}{$\begin{array}{l}5 \% \text { higher Elasticity } \\
\text { of Asset Substitution }\end{array}$} & \multicolumn{5}{|c|}{$\begin{array}{l}5 \% \text { lower Elasticity } \\
\text { of Asset Substitution }\end{array}$} \\
\hline & $\mathrm{FB}$ & DGB & FGB & $\mathrm{FE}$ & $\mathrm{APF}$ & $\mathrm{FB}$ & DGB & FGB & $\mathrm{FE}$ & APR \\
\hline \multicolumn{11}{|l|}{ Net Return $^{1)}$} \\
\hline Initial Value & 2.40 & 2.06 & 2.06 & 8.10 & 4.70 & 2.40 & 2.06 & 2.06 & 8.10 & 4.70 \\
\hline Short-Run Value & 3.17 & 2.72 & 2.72 & 8.54 & 5.05 & 3.17 & 2.72 & 2.72 & 8.52 & 5.05 \\
\hline Long-Run Value & 2.82 & 2.43 & 2.54 & 8.08 & 4.70 & 2.88 & 2.49 & 2.62 & 8.19 & 4.70 \\
\hline \multicolumn{11}{|l|}{ Gross Return ${ }^{1)}$} \\
\hline Initial Value & 4.30 & 3.70 & 3.70 & 10.1 & 6.53 & 4.30 & 3.70 & 3.70 & 10.1 & 6.53 \\
\hline Short-Run Value & 4.28 & 3.65 & 3.66 & 11.4 & 6.89 & 4.29 & 3.64 & 3.66 & 11.4 & 6.89 \\
\hline Long-Run Value & 3.83 & 3.31 & 3.45 & 10.8 & 6.32 & 3.82 & 3.29 & 3.44 & 10.8 & 6.32 \\
\hline \multicolumn{11}{|l|}{ Portfolio Share ${ }^{2)}$} \\
\hline Initial Value & 15.8 & 6.95 & 34.4 & 42.8 & 100 & 15.8 & 6.95 & 34.4 & 42.8 & 100 \\
\hline Short-Run Value & 17.0 & 7.13 & 35.5 & 40.3 & 100 & 17.0 & 7.12 & 35.5 & 40.3 & 100 \\
\hline Long-Run Value & 16.8 & 7.27 & 37.7 & 38.2 & 100 & 16.8 & 7.25 & 37.5 & 38.5 & 100 \\
\hline \multicolumn{11}{|l|}{ Asset Volume } \\
\hline Short-Run Change ${ }^{2)}$ & 6.95 & 1.38 & 1.81 & -7.12 & - & 6.68 & 1.40 & 1.84 & -6.84 & - \\
\hline Long-Run Change ${ }^{2)}$ & 17.5 & 15.2 & 20.4 & -1.74 & - & 16.9 & 14.6 & 19.4 & -1.38 & - \\
\hline
\end{tabular}

Source: Own calculations. 
The elasticity of asset substitution has an impact on the long-run steady-state equilibrium reached after the 2008 reform. A higher (lower) value for the respective elasticity implies that the different assets can be more (less) easily substituted. Thus, the tax-induced portfolio adjustments become more (less) pronounced and create a higher (lower) level of disinvestments in the corporate sector. The latter results in a stronger (weaker) negative effect on the long-run steady-state equilibrium. Accordingly, the aggregate output, investment and employment are lower (higher), the higher (lower) the applied value for the elasticity of asset substitution. For a $2(10)$ per cent variation in the value of the elasticity, the discrepancy in long-run macroeconomic outcomes appears at the second (first) decimal place. In summary, the discrepancies are more accentuated for long-run output, investment and employment but less pronounced for long-run household consumption and welfare.

Table 10: 2008 Reform, Foreign Firm-Ownership 40\%

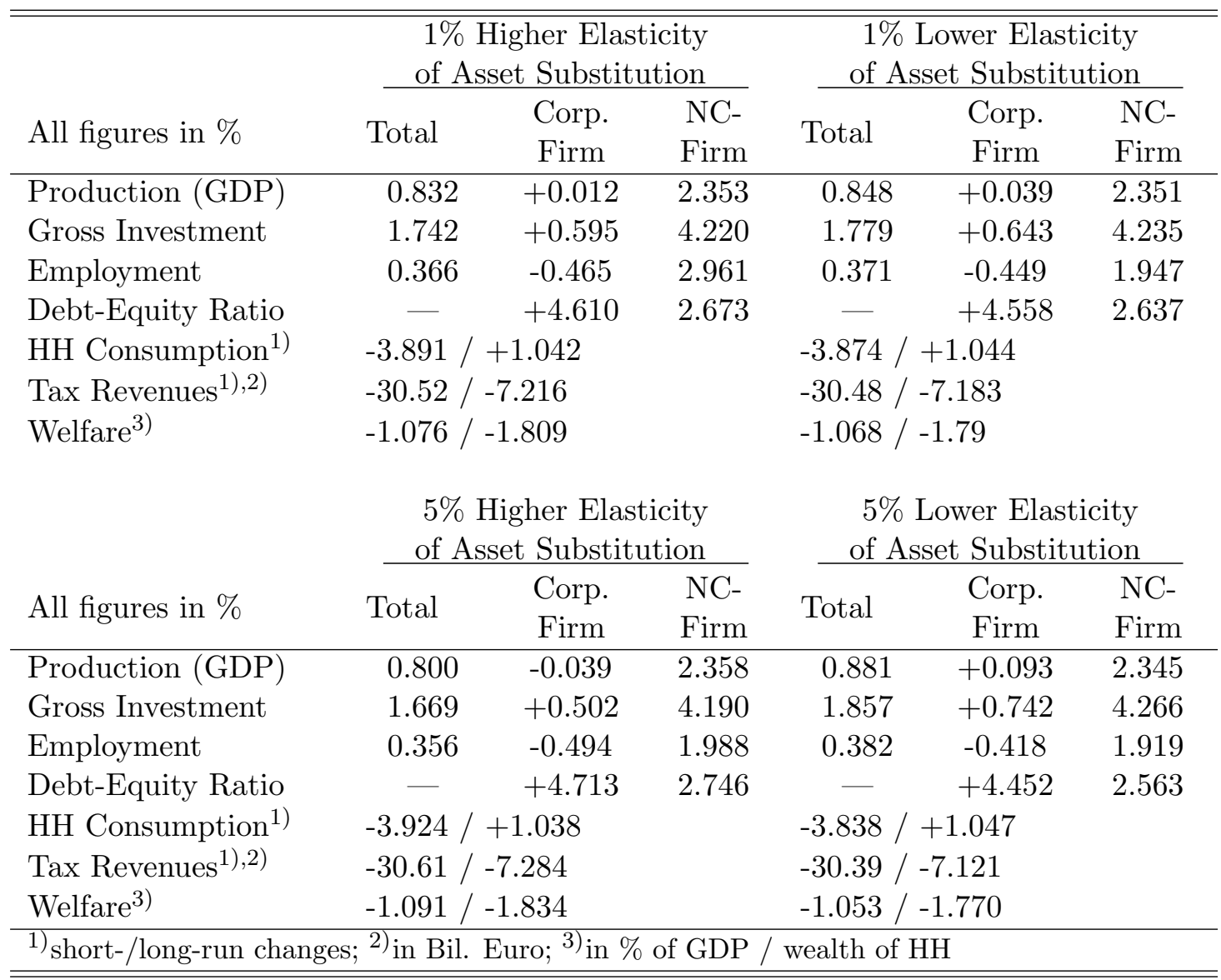

Source: Own calculations.

\section{A.2 Elasticity of Inter-temporal Substitution}

The variation in the elasticity of inter-temporal substitution has no impact on the long-run steady-state equilibrium reached after the reform. The long run estimates for production, investment and employment are of an identical size despite the change in the respective 
elasticity value. In addition, the resulting shift in household consumption and welfare is very limited. In the case of a 5 per cent higher (lower) elasticity of inter-temporal substitution, the drop in short-run consumption becomes slightly more (less) pronounced, while the longrun consumption profile remains the same, explaining the moderate decrease (increase) in welfare.

Table 11: 2008 Reform, Foreign Firm Ownership 40\%

\begin{tabular}{|c|c|c|c|c|c|c|}
\hline \multirow[b]{2}{*}{ All figures in \% } & \multicolumn{3}{|c|}{$\begin{array}{l}\text { 1\% Higher Elasticity of } \\
\text { Intertemp. Substitution }\end{array}$} & \multicolumn{3}{|c|}{$\begin{array}{l}1 \% \text { Lower Elasticity of } \\
\text { Intertemp. Substitution }\end{array}$} \\
\hline & Total & $\begin{array}{l}\text { Corp. } \\
\text { Firm }\end{array}$ & $\begin{array}{l}\mathrm{NC}- \\
\text { Firm }\end{array}$ & Total & $\begin{array}{l}\text { Corp. } \\
\text { Firm }\end{array}$ & $\begin{array}{l}\mathrm{NC}- \\
\text { Firm }\end{array}$ \\
\hline Production (GDP) & 0.840 & +0.025 & 2.352 & 0.840 & +0.025 & 2.352 \\
\hline Gross Investment & 1.761 & +0.619 & 4.227 & 1.761 & +0.619 & 4.227 \\
\hline Employment & 0.369 & -0.457 & 1.954 & 0.369 & -0.457 & 1.954 \\
\hline Debt-Equity Ratio & - & +4.581 & 2.653 & - & +4.587 & 2.657 \\
\hline HH Consumption ${ }^{1)}$ & \multicolumn{3}{|c|}{$-3.897 /+1.043$} & \multicolumn{3}{|c|}{$-3.867 /+1.043$} \\
\hline Tax Revenues ${ }^{1,2)}$ & \multicolumn{3}{|c|}{$-30.52 /-7.199$} & \multicolumn{3}{|c|}{$-30.47 /-7.199$} \\
\hline Welfare $^{3)}$ & \multicolumn{3}{|c|}{$-1.072 /-1.803$} & \multicolumn{3}{|c|}{$-1.072 /-1.802$} \\
\hline \multirow[b]{2}{*}{ All figures in \% } & \multicolumn{3}{|c|}{$\begin{array}{l}5 \% \text { Higher Elasticity of } \\
\text { Intertemp. Substitution }\end{array}$} & \multicolumn{3}{|c|}{$\begin{array}{l}5 \% \text { Lower Elasticity of } \\
\text { Intertemp. Substitution }\end{array}$} \\
\hline & Total & $\begin{array}{l}\text { Corp. } \\
\text { Firm }\end{array}$ & $\begin{array}{l}\mathrm{NC}- \\
\text { Firm }\end{array}$ & Total & $\begin{array}{l}\text { Corp. } \\
\text { Firm }\end{array}$ & $\begin{array}{l}\mathrm{NC}- \\
\text { Firm }\end{array}$ \\
\hline Production (GDP) & 0.840 & +0.025 & 2.352 & 0.840 & +0.025 & 2.352 \\
\hline Gross Investment & 1.761 & +0.619 & 4.227 & 1.761 & +0.619 & 4.227 \\
\hline Employment & 0.369 & -0.457 & 1.954 & 0.369 & -0.457 & 1.954 \\
\hline Debt-Equity Ratio & - & +4.572 & 2.644 & - & +4.598 & 2.667 \\
\hline HH Consumption ${ }^{1)}$ & \multicolumn{3}{|c|}{$-3.957 /+1.043$} & \multicolumn{3}{|c|}{$-3.807 /+1.043$} \\
\hline Tax Revenues ${ }^{1), 2)}$ & \multicolumn{3}{|c|}{$-30.63 /-7.199$} & \multicolumn{3}{|c|}{$-30.34 /-7.199$} \\
\hline Welfare $^{3)}$ & \multicolumn{3}{|c|}{$-1.072 /-1.803$} & \multicolumn{3}{|c|}{$-1.071 /-1.801$} \\
\hline
\end{tabular}

Source: Own calculations. 